\title{
Suffer the little children some autonomy
}

\author{
Vivienne Wachenje Essex
}

\section{Editor's note}

'At the coalface' is a series in which health care workers actually faced with moral issues in their work are encouraged to describe them, with as much or as little analysis as they wish. Here an Essex County Council employee who works with handicapped children reflects on the mutuality of learning.

\section{Author's abstract}

There exist layers of disparity between perspectives and perceptions of handicap or disability. Handicap is frequently seen by the able-bodied (and minded), as a condition unrelated to themselves. Learned articles appear in specialist journals, but lost in the relentless tidal wave of words, is the very real personality of that handicapped individual ... not waving, but drowning.

Socrates believed that the unexamined life is not worth living (1) so I have put myself imaginatively under the eye of Christopher Nolan's (2) scrutiny - for who has the right to examine whom?

In my naivety, I once asked the educational experts how the intelligence of the handicapped is measured. I did not err willingly, but through ignorance, for I came to appreciate that intelligence is commensurate with the development of a sense of humour.

The child was cute. He knew I was new. Fumbling, inexpert, but yet with such a weighty handicap on my part, I was asked to give this athetoid child a drink.

I watched as the teacher demonstrated the skill with which this is done, and then, vulnerable and selfconscious, I faced the sparkling mischief of his eyes. He had the trump card, he could orchestrate a superfluity of wobbling!

I failed him, I spilt his drink.

From now onwards, I must school myself and nurture the presentation of a calm presence. I must watch others more skilled than I, learn the technique. In time, I was able to demonstrate the art to to others.

\section{Key words}

Athetosis; therapy-ball; angels; osteogenesis imperfecta; reasonable parent standard; thought-facility.
There is another child, the 'bruised-fruit' of a medically mismanaged birth. We hit it off from the start. She is much prettier than I, with her curling lashes and bright impish smile. She laughs at me when I do things wrong, or some classroom drama occurs.

But, she has honoured me by becoming my friend. In the swimming pool or on the therapy-ball, she will lift her arms in order to embrace me. She is not mean with her affection as I have sometimes been.

To be part of the world of the handicapped is to enter a landscape of privilege - for here are persons who are neither ambitious, avaracious, or indeed, bothered by academic or metaphysical argument. They simply are.

I keep trying to convert to atheism, but this child makes me ponder whether we 'entertain an angel unawares' (3).

Having said all this, I do not mean to imply that the handicapped should exist simply to make us, through caring for them, 'better' people. It would be wrong to underestimate the enormous professional input required to ensure that their lives are invested with meaning. It would also be a disservice to pretend that the lives of the parents/carers, do not incur very real limits to their autonomy.

This point was made in 'The Search for a Perfect Baby' (4), and I quote:

'A number of speakers drew attention to the fact that, though there has been a growth in the capacity to care for the newborn handicapped baby, this is not matched by help through the life time of the growing child.'

Similarly, a brief article in the Nursing Times, (5) describes how the parents of children with osteogenesis imperfecta, for example, accommodate to the needs of their children in order to lead some semblance of family life, and again I quote:

'The management behaviours are accommodations by the family and its members to the abilities and disabilities of the disabled child. They are the family's entrée to a normalised existence, and the nurse's entrée to understanding their world.'

From the 'Reasonable Parent Standard', it is only proper to desire the procreation of children who will 
hopefully take their place in the world as autonomous individuals. But given the complexity of the human body, the real miracle is health.

It is right and good to try to eliminate, or at least, limit, the likelihood of handicap. Yet it is extraordinarily difficult to imagine or envisage a world where all that is 'undesirable' is eradicated, because it is the striving after Utopia, and the quest for excellence of care, that gives life meaning. (The Myth of Sisyphus writ large.)

I believe the presence of the handicapped disturbs us at a fundamental level, because they expose the raw nerve of the variety of disabilities present in us all. It may well be that profoundly handicapped persons are incapable of self-reflection, but it is certainly true that many so-called able-bodied people fail to exercise fully their unique thought-facility.

Again, who has the right to examine whom?

Christopher Nolan is more eloquent than I on this subject, so I will end with a quote from his first book (6) (CRC refers to the Central Remedial Clinic):

'A loser all the way

$A$ leap in the CRC,
A look past all a man

Appears to be',

Vivienne Wachenje BA, Dip ME and Laws was formerly a Welfare Assistant in a Special Educational Needs School, and gives regular research ethics lectures to research nurses.

\section{References and notes}

(1) Plato: The last days of Socrates. Apology. Harmondsworth: Penguin Classics, 1972, translated by Hugh Tredennick.

(2) Christoper Nolan is a writer who happens to be disabled. $\mathrm{He}$ is author of Under the eye of the clock and winner of the 1987 Whitbread Book of The Year Award.

(3) New Testament: Hebrews Ch 13 v 2.

(4) IME Bulletin 1986 Feb 11. Report by Vivianne de Vahl Davis.

(5) A brief report in The nursing times 1988 Jun 8: 59 quotes from The journal of advanced nursing 1988;13: 15-21.0 Deatrick J A, Knarl K A, Walsh M. Accommodating disabled children: the process of parenting a child with disability: normalisation through accommodations.

(6) Nolan C. Dam-burst of dreams:33. From: My earliest memories of the CRC. 